\title{
Confrontations in the historical part of Shahnameh with the approach of Louis Strauss
}

\section{Enfrentamientos en la parte histórica de Shahnameh con el acercamiento de Louis Strauss}

\author{
Maryam alavi \\ $\mathrm{PhD}$ student in Persian Language and Literature, Islamic Azad University, Mashhad Branch, \\ Iran

\section{Parvin dokht mashhur} \\ Member of the Department of Persian Language and Literature, Islamic Azad University, \\ Mashhad Branch, Iran

\section{Mahammad fazeli} \\ Member of the Department of Persian Language and Literature, Islamic Azad University, \\ Mashhad Iran Branch
}

Received 07-08-20 Revised 08-10-20

*Correspondence

Email: dokhtmashhur@gmail.com
Accepted 09-02-20 On line 03-06-21

Cite as:

alavi, M., mashhur, P., \& fazeli, M. (2021). Confrontations in the historical part of Shahnameh with the approach of Louis Strauss. Propósitos y Representaciones, 9(SPE3), e1093. Doi: http://dx.doi.org/10.20511/pyr2021.v9nSPE3.1093 


\section{Summary}

The opposition of the opposites is also reflected in the myth of the nations and one of the main fields of the myth is the struggle of different forces. Myth is the mother of epic, and any nation that does not have a myth is also useless of epic, and the main background of the epic of any nation is its myth. So this fundamental concept has also found its way into the epic; But in the process of materialization of phenomena from myth to epic, mythical concepts are formed differently in the epic, and during this process, the confrontation of human beings or heroes with evil forces, the confrontation of two tribes and clans, The two heroes become one with each other. In general, it can be said that epic is the fruit of man's struggle with anything that is against his dreams and aspirations and in opposition to his will and action. Meanwhile, the contrast between the phenomena of nature such as night and day, darkness and light, drought and wet season, greenery and autumn and the like, had caused the human way of thinking and worldview based on the same contrast. And as a result, human mythology is full of these contradictions. Moreover, even in later periods, such a way of thinking has prevailed in the human mind and historical data have been analyzed and explained based on this approach. Another important factor in the existence of confrontation and contradiction in mythology is the existence of secondary ideas in these works; Because the important principle in the dual thought of the myths of ancient Iran is the conflict between the demonic forces and the Ahura forces, which considers the whole world as the place of these two opposing forces; Influenced by this idea, we always encounter confrontation and war between groups in Shahnameh. One of the important sources and a collection of myths and legends and even valuable historical contents of this region is Ferdowsi's Shahnameh, which is divided into three parts: mythology (from the time of Kiomars to the kingdom of Fereydoun), heroism (from the rise of the blacksmith to The assassination of Rostam and the reign of Bahman, son of Esfandiar) and historical (from the reign of Bahman and the birth of Alexander to the opening of Iran to the Arabs) has been divided.

Keywords: Shahnameh, Contrast according to Louis Strauss, Historical Section, Bahram Gore

\section{Resumen}

La oposición de los contrarios también se refleja en el mito de las naciones y uno de los principales campos del mito es la lucha de diferentes fuerzas. El mito es la madre de la epopeya, y cualquier nación que no tenga un mito también es inútil de la epopeya, y el trasfondo principal de la epopeya de cualquier nación es su mito. Así que este concepto fundamental también se ha abierto camino en la épica; Pero en el proceso de materialización de los fenómenos del mito a la épica, los conceptos míticos se forman de manera diferente en la épica, y durante este proceso, el enfrentamiento de los seres humanos o héroes con las fuerzas del mal, el enfrentamiento de dos tribus y clanes, los dos héroes se convierten en uno con el otro. En general, se puede decir que la épica es el fruto de la lucha del hombre con todo lo que está en contra de sus sueños y aspiraciones y en oposición a su voluntad y acción. Mientras tanto, el contraste entre los fenómenos de la naturaleza como la noche y el día, la oscuridad y la luz, la sequía y la estación húmeda, el verdor y el otoño y similares, había provocado que la forma humana de pensar y la cosmovisión se basaran en el mismo contraste. Y como resultado, la mitología humana está llena de estas contradicciones. Además, incluso en períodos posteriores, tal forma de pensar ha prevalecido en la mente humana y los datos históricos se han analizado y explicado con base en este enfoque. Otro factor importante en la existencia de enfrentamientos y contradicciones en la mitología es la existencia de ideas secundarias en estas obras; Porque el principio importante en el pensamiento dual de los mitos del antiguo Irán es el conflicto entre las fuerzas demoníacas y las fuerzas de Ahura, que considera al mundo entero como el lugar de estas dos fuerzas opuestas; Influenciados por esta idea, siempre encontramos enfrentamientos y guerras entre grupos en Shahnameh. Una de las fuentes importantes y una colección de mitos y leyendas e incluso valiosos contenidos históricos de esta región es Shahnameh de Ferdowsi, que se divide 
en tres partes: mitología (desde la época de Kiomars hasta el reino de Fereydoun), heroísmo (desde el surgimiento del herrero hasta El asesinato de Rostam y el reinado de Bahman, hijo de Esfandiar) e histórico (desde el reinado de Bahman y el nacimiento de Alejandro hasta la apertura de Irán a los árabes) se ha dividido.

Palabras clave: Shahnameh, Contraste según Louis Strauss, Sección histórica, Bahram Gore

\section{Introduction}

The opposition of the opposites is also reflected in the myth of the nations and one of the main fields of the myth is the struggle of different forces. Myth is the mother of epic, and any nation that does not have a myth is also useless of epic, and the main background of the epic of any nation is its myth. So this fundamental concept has also found its way into the epic; But in the process of materialization of phenomena from myth to epic, mythical concepts are formed differently in the epic, and during this process, the confrontation of human beings or heroes with evil forces, the confrontation of two tribes and clans with each other, The two heroes become one with each other. In general, it can be said that epic is the fruit of man's struggle with anything that is against his dreams and aspirations and in opposition to his will and action.

This worldview is prevalent throughout the Shahnameh. Ferdowsi considers the instrument of the world in constant conflict with each other. Concepts such as tyranny, death and life, good and evil, predestination and free will are contradictory concepts that have always been the focus of Shahnameh stories; Therefore, the reflection of confrontations, contradictions and conflicts in the stories of Shahnameh is obvious, and since the epic is the manifestation of the national spirit and includes religion, religion, politics, society, and even the geographical environment, etc. To take. All these different things in opposition to each other, lead to the formation of different confrontations and conflicts in the stories of Shahnameh.

In general, the study of Shahnameh shows that the element of contrast is reflected in it, which of course is one of the common features of all epic works in the world. More precisely, the element of confrontation and contradiction is manifested in all parts of the Shahnameh, including the mythological, heroic and historical parts, and the study of this element can be interesting results in the field of the effect of the element of confrontation in the formation of stories. Give Shahnameh.

The study of epic and mythological works using new theories is one of the new approaches in research related to mythology. One of these theories, based on the study of the element of contrast in epic works, was the theory of Claude Lévi-Strauss (November 28, 1908 - October 30, 2009), a French ethnographer and anthropologist and one of the theorists of modern anthropology. Which has provided theories in all its key areas. According to Levi-Strauss, the goal of structuralist anthropology is to penetrate the underlying layers and focus on "mechanisms" rather than on people and their behaviors. Levi-Strauss later developed this approach and used it in his later works to explore myths more prominently. He was eager to reduce myths to their constituent units and to show how the combination of these units could be understood along the contrasting boundaries between life and death, nature and culture, and raw materials and food. He believed that these contradictions help to explain the diversity of mythmaking, and this is a point which shows that by placing myths under the heading of "universal" one cannot reveal a perception of it. Beigi, 1392: 115)

According to Strauss, "the structure of the human mind to perceive phenomena places every continuum in dual poles, and this pervasive mental action eventually leads to dual contrasts such as night / day, black / white." , Raw / cooked and such concepts. He believes that in a structuralist study, the chain of doubt of the components cannot be ignored. Therefore, any general opposition in myth must be divisible into more detailed oppositions. Of course, this decomposition Continuous detachability does not mean that mythical biodegradability means 
disconnecting the part from the whole; Rather, the action and meaning of any microconfrontation is always in the direction of a larger confrontation. "(Ebadi Jamil et al., 2016: 67)

Considering that the element of confrontation and conflict is significant in the place of Shahnameh and the attack in its historical part, for this reason, in this article, we intend to confront the confrontations in the story from the historical part of Shahnameh (Bahram Goor) with the approach of confrontation. Let us examine and analyze Louis Strauss to determine what role the element of opposition plays in the structure of this story.

\section{Problem Statement}

In general, the study of Shahnameh shows that the element of contrast is reflected in it, which of course is one of the common features of all epic works in the world. More precisely, the element of confrontation and contradiction is manifested in all parts of the Shahnameh, including the mythological, heroic and historical parts, and the study of this element can provide interesting results in the field of the effect of the element of confrontation in the formation of stories. Give Shahnameh.

The study of epic and mythological works using new theories is one of the new approaches in research related to mythology. One of these theories, based on the study of the element of contrast in epic works, was the theory of Claude Lévi-Strauss (November 28, 1908 - October 30, 2009), a French ethnographer and anthropologist and one of the theorists of modern anthropology. Which has provided theories in all its key areas. According to Levi-Strauss, the goal of structuralist anthropology is to penetrate the underlying layers and focus on "mechanisms" rather than on people and their behaviors. Levi-Strauss later developed this approach and used it in his later works to explore myths more prominently. He was eager to reduce myths to their constituent units and to show how the combination of these units could be understood along the contrasting boundaries between life and death, nature and culture, and raw materials and food. He believed that these contradictions help to explain the diversity of mythmaking, and this is a point which shows that by placing myths under the heading of "universal" one cannot reveal a perception of it. Beigi, 1392: 115)

According to Strauss, "the structure of the human mind to perceive phenomena places every continuum in dual poles, and this pervasive mental action eventually leads to dual contrasts such as night / day, black / white." , Raw / cooked and such concepts. He believes that in a structuralist study, the chain of doubt of the components cannot be ignored. Therefore, any general opposition in myth must be divisible into more detailed oppositions. Of course, this continuous decomposition does not mean that mythical decomposition means the disconnection of part and whole; Rather, the action and meaning of any micro-confrontation is always in the direction of a larger confrontation. "(Ebadi Jamil et al., 2016: 67)

Considering that the element of confrontation and conflict is prominent in the place of Shahnameh, including in its historical part, for this reason, in this research, we intend to briefly address the confrontation in one of the historical stories of Shahnameh (Bahram Gour).

\section{Background}

A search of books, articles and research databases such as Irandak, Normagz, Mgiran and SID indicates that so far no comprehensive research has been conducted on the study of contrasts in the historical part of Shahnameh with the approach of Louis Strauss. And this article is the first step in this direction. Of course, in several researches, the mythological and heroic parts of Shahnameh have been studied based on Levi-Strauss theory, which can be considered as the background of this treatise. Of course, in general, from one point of view, all the researches that have been written in the field of studying the contrast in Shahnameh stories based on LeviStrauss theory are considered as the research background of this treatise, but since These researches are many and mentioning them causes the elaboration of the word, so we will suffice to introduce some important researches in the field of studying the contrast in Shahnameh 
stories and, if necessary, in the text of the treatise, We will have references to some related research.

- Parvin Peykani (1397) in her doctoral dissertation entitled "Analysis of the mythological and epic part of Shahnameh based on the structuralist theory of Claude Levi-Strauss" has concluded that the dual Ahuraian / demonic (good / evil), Iranian / Iranian, Nature / culture, the importance of family ties / underestimating family ties, father / son, woman / man, old age / youth, intramarital / extramarital affairs, native / patriarchal as well as the confrontation of two patriarchal / patriarchal cultures are the most important confrontations of these two parts of Shahnameh. He believes that some of the hidden implications of the stories are as follows: the thinking of the plant body of man against a single source in the creation of man, the change of the period of human sacrifice in fertility mirrors and the replacement of the animal in his place; Drought and desert struggle with greenery and land fertility; The catastrophic creation of native residence, etc., each of which reflects a part of Iranian culture.

- Abolfazl Mohebbi (2016) in his master's thesis entitled "Study of the Shahnameh pre-period from the perspective of Levi Strauss mythological structuralism" has concluded that the structure of all the myths of the Shahnameh period is based on There are three opposites: sacred / unholy, power / decline of power, and nature / culture. The sacred / unholy and nature / culture confrontations are themselves a subset of the power / power decline confrontation.

Mohammad Chaharmahali et al. (1398) in an article entitled "Analysis of double confrontation in the story of Jamshid based on the theory of Levi Strauss" have concluded that in the present According to Jamshid, there are clearly two types of opposition: "dual cause and effect" and "dual contradiction". Based on these two types of contrasts, the final meaning of each phonological myth and the general meaning of the reciprocal periods of Jamshid's story are expressed. The authors of the article have also concluded from the final analysis of the story's dual confrontations that because the myths of the words of Jamshid's ingratitude period are more than his thanksgiving period, the end of the story leads to his destruction and the humiliation of the Iranians.

- Rahman Zabihi and Parvin Peykani (1396) in an article entitled "Analysis of the structure of the myth of Giomard based on the theory of Levi Strauss" have concluded that the confrontation of Giomard with the devil is a reflection of the opposition of good and evil that underlies the dual thinking of Iranians Constitutes. Also, the continuous absence of Guillaume as the representative of mankind with the devil indicates the continuation of the cycle of life and death; In this way, Guillaume defeats the devil in the process of his life and overcomes the devil with his death, and the devil inadvertently ends the limited time and fails.

- Mohammad Chaharmahali et al. (2017) in an article entitled "The confrontational structure of Siavash's story in Shahnameh based on the theory of Levi Strauss" have concluded that "confrontation" in the mythical-epic story of Siavash in Shahnameh is significant and as One of the most important building blocks in the existence of characters and events has shown itself. Underlying all the events in this story are the two reciprocal principles of "overestimating kinship" and "underestimating kinship" in Levi-Strauss theory. There are two types of confrontation in this story: 1. Internal confrontation which observes the conflict between Soodabeh and Siavash in the land of Iran and Kikavous harem, which makes Siavash proud and then rejects him, and also observes the conflict between Kaykhosrow and Fariborz on the one hand and the conflict. Toos and Goodarz are in favor of these two characters in the issue of Kikavous succession on the other hand. The main excuse in this type of confrontation is kinship and inbreeding, and the so-called Levi-Strauss is highly valued. 2. An external confrontation that oversees Afrasiab's greedy and conspiracy with Siavash and causes his death. The main excuse in this kind of confrontation is the long-standing alienation and enmity and the same underestimation. Also, the principle of overestimating the sleep of Afrasiab and Siavash on the one hand and the principle of underestimating the sleep of Piran Vise and Goodarz Keshavadegan on the other hand. 
- Saeed Ebadi Jamil et al. (2016) in an article entitled "Study of the myth of Zahak based on the structure of the double confrontations of Claude Louis Strauss" have concluded that confrontations such as the confrontation between Iranians and Iranians, lion and blood, Kaveh and Zahak, the communal society and the centralized government, Shahrnaz, Arnavaz and the future confrontations of Shahnameh, etc. all serve the general confrontations and in order to strengthen the fundamental reciprocal aspects of the myth.

- Ruhollah Hosseini and Assadollah Mohammadzadeh (2006) in an article entitled "Study of the structure of the confrontation between Rostam and Esfandiar in Shahnameh based on the theory of Levi-Strauss confrontation" have concluded that according to the theory of Levi-Strauss confrontation, two functions The main text of the text can be considered to be based on the internal and external parallels of the two main characters of the story, namely Rostam and Esfandiar. The first function, which is mostly related to storytellers and fans of the two fronts, and also relies on the external symmetries of the two-hero environment, is interpreted as an intellectual function and deals with the ideas behind this confrontation. The second function, which goes back to the inner parallels of the two heroes, has been interpreted as the epic function of the story. Examining the evidence in the story and in the context of these two functions, we find that the reason for the tragedy of Esfandiar's death is due to the internal factors that motivated the two heroes to face each other and not to external factors such as Goshtasb and Jamasp.

The present research has been expressed in an analytical-descriptive method and information collection in this research has been compiled in a documentary and library manner and references to articles and internet sites by the method of taking notes and classifying receipts and classifying them in line with the research subject.

\section{Shah nameh:}

Shahnameh by Hakim Abolghasem Ferdowsi Tusi is a poetic epic in the consecrated sanctuary of the deleted Mutman and approximately sixty thousand verses is one of the largest and most prominent epic works in the world, the composition of which has lasted for nearly thirty years. "I suffered a lot this year. Myth, the legend and history of Iran from the beginning of the conquest of Iran by the Arabs in the seventh century, which are summarized in four periods of monarchy: Pishdadians, Kianians, Parthians and Sassanids. It is divided into three parts: mythology, heroism and history. The search was "Shahnameh of Abu Mansouri".

\section{The subject of Shahnameh stories}

Shahnameh is a description of the circumstances, victories, defeats, failures and heroism of the Iranians from the oldest period (the first king of the world Kiomers) to the overthrow of the Sassanid government at the hands of the Tazians (in the seventh century AD).

The foreign conflicts of the Iranians are with the Indians in the east, the Turanians in the east and northeast, the Romans in the west and northwest, and the Tazians in the southwest.

In addition to the historical course of the story, there are scattered independent stories in Shahnameh that are not directly related to the historical course. Among them: the story of Zal and Rudabeh, Rostam and Sohrab, Bijan and Manijeh, Bijan and Grazan, Karam Haftavad and others, some of these stories, such as Rostam and Esfandiar or Rostam and Sohrab, are among the undoubted masterpieces of world literature. .

"Part of the Shahnameh is an ancient myth and legend that has been passed down from the past to the future from very ancient times, and has naturally found its way into the narratives over time. Another part of this legend It contains the history of the ancestors of the Iranians, which dates back to prehistoric times, and goes back to very distant times when the ancestors of the Iranians and the Indians lived together. The reason for this is that some of these legends can also be seen in very ancient Indian works. The names of such personalities as Jamshid, 
Fereydoun, Kavous, and Kaykhsaro appear both in the ancient Iranian writings of the Avesta and in the ancient Indian writings of Riguda. Another part of Shahnameh is historical narrations. "Some of these narrations are more and some are less intertwined with myths." (Kurt, 1374: 66)

"Ferdowsi, by creating his great epic, objectified the confrontation between the two cultures of Iran and Islam in the best possible way. By reflecting on the Shahnameh and understanding the intellectual background of the Iranians and the type of their thoughts and customs, we realize that The Iranians, as a fertile and fertile land, are ready to receive the seeds of the new divine religion and have themselves embraced this monotheistic religion. As in the early years of the advent of Islam, they worked hard to spread and defend and defend its rules and laws. "(Hamidi, 1371: 78)

The importance of the Shahnameh is not limited to its literary and poetic aspect, and before it is a collection of poetic stories, it is a genealogy whose bitterness and professionalism are rooted in the depths of desires and desires. Collective nations have an ancient nation. A nation that has praised goodness and enlightenment in all historical periods and has fought against evil and darkness.

\section{Reflection of contrast in Shahnameh and other epic works}

Confrontation can be considered the most important element of epic works because such works are always a place of conflict and confrontation between the forces of good and evil and all human beings and characters in epic works are in one of the circles of good or evil. And in this way they find their identity.

In other words, since man in the past was unable to rationally interpret phenomena due to ignorance and lack of science and knowledge, so in order to interpret and analyze phenomena, seeing any force in nature, Through his childish arguments, he divided it into good and bad. The division of peripheral factors into the forces of good and evil is a fundamental issue in the mythology of nations and has formed the common theme of many myths, this issue in Iran.

Due to the connection between the two indigenous peoples living on the Iranian plateau and the Indo-Iranian immigrant tribes who had many things in common and were in great need of the stability of society and the maintenance of order, it has found a pivotal role in this land.

Epic, then, is inherently a place of conflict and conflict, and inevitably confronts the forces of good or evil. Just like nature itself, which is a collection of contradictions; Cold and heat, night and day, etc. The Valley of Life, Nature, and the Nature of Life The miscreants and companions are always flowing, as long as the world exists. "In Iranian mythology, human behavior is inherently epic. The Forouhars choose goodness at their own discretion and become gentian, willful, and put it into action. The epic man is a confrontation of existence "other than himself" in order to fall into the destiny of which the world is his birthplace and to build his own destiny. "In this life of will and action, the forces of this world and that world are with him or against him and sometimes against him." (Moskoob, 103: 1370)

The epic world without movement is a dead world. "Only death can remove an epic man from the field. The epic man, wherever he is on the field, good or bad, must strive to achieve his sacred ideal. The pious and each have a philosophy for their method. For one who watches the game from the outside and with his pure wisdom can distinguish between good and evil, otherwise the bad ones will consider themselves righteous. "(Ibid: 104)

In the world of epic, everything is alive, because the foundation of every epic and the epic mechanism of movement has been laid, its struggle and rivalry and conflict. What separates and recognizes the epic from the myth is only this structural and fundamental feature. The epic is a myth that has taken on a heavenly dimension. "Mino" in essence and nature is uniform and simple to the period of struggle and strife, but the incompatibility and duality lies in the valley of nature. Each gothic phenomenon has its own inconsistencies and inversions. Shouts, good 
and bad, of this kind. Hence, the inverted universe of Mino, ruled by eternal silence and tranquility, is the space of times, the center of effort and endeavor and invasion. On this basis, it can be said that all mechanisms and trends in the universe have an epic nature and structure, because epic is nothing but the conflict of the incompatible with each other. "(Kazazi, 1360: 660)

The discussion of opposition in mythology is related to the doctrinal issue of dualism, and the belief in duality is one of the basic beliefs in ancient Iran. "Duality is a characteristic of Zoroastrian religion and it is the belief in two fundamentally opposite forces that are involved in the world." (Hinels, 1386: 65) It seems that this dual force is seen in all beings as All phenomena of existence in ancient Iran have gods and demons or forces of good and evil. Each element has two sides and two effects, one good effect and the other bad effect.

The institutionalization of duality in human nature is undeniable, something that is interpreted as the essence of blame and the essence of matter, and the only issue is about its limits and conditions in different cultures and religions. This factor caused man to take steps to understand his human place, because he considered himself the possessor of memory and language, and this understanding caused him to see himself beyond other beings and to build concepts about himself and outside himself in his own place. . These concepts sometimes took on a completely abstract form and were sometimes the product of his interaction or confrontation with various forces or events. Maf Ahimi, who, along with his religious teachings, guided him towards a good life and showed the proper way of life in this world. "Angeldemon", "good-evil", "god-devil" and ... are examples of the most ancient and long-standing ways of expression and human interaction with his inner duality. The confrontation of good and evil began in the heart of ancient myths and has been passed down from generation to generation in stories. Myths are interpretations of the sacred, stories that belong to God or the Lord of sorts or superhuman or divine beings. Things that happened in the past and belong to ancient cultures.

Thus, the conclusion is that "the invasion of darkness into the world of light is undoubtedly a very old myth, and this duality and conflict between light and darkness is a doctrine that goes back to the time of the common life of the Aryan, Indo-European, Indo-Iranian peoples. It is found and therefore found in all Indo-European tribes with intensity and weakness. For example, another myth of Prometheus ("In Greek mythology, the god of fire and the creator of mankind and the manifestation of human genius" (Moein, vol. 5, 1371: 1371) with Zeus (in Persian literature, a star named Hormuz, which according to the Greeks In the name of Zeus and later among the Romans, in the name of Jupiter, it was also the name of their greatest lord. (Ibid: J 5: 341)) The turmoil and chaos of the abyss to the emerging gods, who all submitted to Marduk, and Marduk was first defeated by them and then defeated the enemies, and created the heavens and the earth from the carcass of his enemy. It can be counted. "(Sattari, 2006: 118117)

\section{The category of confrontation in ancient Iran}

The division of peripheral factors into the confrontation of the forces of good and evil is a fundamental issue in the myths of nations and has formed the common theme of many myths. And have been very much in need of the stability of society and the maintenance of order, has found a pivotal role in this land.

Dualism, which is the foundation of Iranian culture, is a very surprising and mysterious category that has attracted the attention of all the great thinkers of the mythological history of the world. These dichotomies, contradictions, and contradictions in mythology are the source of all the rebellions that form the dough of strife from the beginning to the end of creation. These battles produce stories with valuable messages that guide and guide many 
It was one of the secrets and mysteries of creation in order to facilitate the life of the future and the interpretation of phenomena in dealing with the sufferings and problems of the universe and natural and supernatural phenomena. "(Noldeke, 1384: 231)

The controversy between good and evil, with the emergence of man, came into existence and perhaps from that moment on, found its external existence and embodiment. The myth of Abel became a symbol of human goodness and the myth of Cain became a symbol of human evil. "Myths and legends have taken their creative and productive energy source from these two (good and evil). The common line that connects all the legends from ancient times to the present is the line of good and evil that forms the two main lines and two pillars of the legends. The forces of evil are on one side and line up and fight against the forces of good, and again the common axis of all myths is the victory of good and the destruction of evil. "(Amoozgar, 2005: 99 )

The dichotomy that forms the basis of all pre-Islamic Iranian theology is sometimes astonishing and confusing. The force of evil is as powerful as the force of good and good, sometimes even the productive force, and the great gods need the help of the smaller gods to overcome him. But such contradictions, while useful in explaining all the complex contradictions of the universe, also explain the intermittent periods that man faces in his life, as well as the endless cycle. Day and night, drought and rain, winter and summer, are embodied and embodied in the form of multiple Iranian gods. Among these, Vaio, the god of the winds, is the best representative of the mountain opposites of the universe. Although he is the mighty right arm of Ahuramazda, his realm is in fact empty where good and evil meet: war and rivalry are the essence of his existence. But the struggle between good and evil, light and darkness, will never reach a definite end, because this struggle is the source and motive of existence. "(Ibid: 211)

Zoroaster believed that the exhausting force in the world as well as in the human psyche flows between the forces of good and evil. He identifies two opposing groups of souls who have been in conflict with each other since the beginning of time, and behind each of these groups stands on one side an army of gods and angels, and on the other side, on the evil side, a multitude of ديوها. Humans are the companions of Ahuramazda in his battle with the devil, whose defeat is the goal and purpose of creation.

Islamic scholars have also considered the belief in Urmazd and the devil or god of goodness and ugliness as the principles of Zoroastrian beliefs. Al-Ghazali, the famous Islamic jurist, writes about the religion of the Moghans: "The Moghans worship absolute light, which includes all light. They believe that he is the god of the world and that all goodness is attributed to him. But because they see that you are in a bad world

There are also, they do not want to attribute them to their God and they want to keep God away from evil. Therefore, they raise the war between light and darkness and attribute the origin of the world to these two, and sometimes they are called God and sometimes the devil. "(AlGhazali, 1368: 25)

To understand the origin of the opposition of the forces of good and evil in the Zoroastrian religion, one must look at the myth of its yellow creation. Please refer. "According to the Zoroastrian tradition, the process of creation and the end of the world takes place over a period of twelve thousand years. The devil confronts Ahuramazda because he has the authority and the right to choose, and in an argument with Ahuramazda, he demands confrontation with him. Ahuramazda, because he is all-knowing and all-knowing, and on the other hand is the God of wisdom and reason, creates this world in order to compete with him. Ahuramazda's purpose in creating the world is to provide a battlefield for confronting and confronting the devil. Of course, this period of twelve thousand years is divided into four periods of three thousand years, in the first period, the world is in the form of Minoan, and in the later periods, Minoan and Gitic. In the first three thousand years, when the world is in the Minoan state and there is no 
mention of place or matter, there are two beings: one is the world belonging to Ormazda, which is full of light, life and goodness, and the other is the world belonging to the devil, which is dark and ugly. Is. In short, in the first three thousand years, Ormazd created Emshaspandan. . In Zoroastrianism, the number of Amshaspandans is six, the first of which is Spantheminio, which means the spirit of increasing, dividing and sacred. Spanteminius is the main symbol of Ahuramazda and his spirit and thought. Due to the dualism in the Zoroastrian religion, the good qualities of Ahura are contrasted with the ugly traits of the devil, and Amshaspandan is contrasted with the komarikana or sardivan. Of course, in this dual system, as it turns out from time to time, Ahura Mazda was not directly against the devil from the beginning, but according to the Gahani tradition, it was Spanta Minio, which was opposite Ingres Minio, but gradually, in the late Sepahan, ». (Teacher, 12: 1380)

In addition to the Avesta, later Ferdowsi's Shahnameh is one of the manifestations of the category of opposition. One of the most important and at the same time the most effective elements that plays an important role in the formation and emergence of the mythological-epic work is the element of personality. "Shahnameh of Ferdowsi is one of the valuable works that is unique in terms of addressing the issue of personality and has become a model for poets and writers in different periods of Iranian history and literature. How many unique works have been created in the post-Ferdowsi period by modeling Ferdowsi's Shahnameh on characterization. Manifestation of the character element in Ferdowsi's Shahnameh and other epics

Mythology and heroism - both internal and external - are exactly when the poet of the epic, the two opposing forces; That is, it juxtaposes good and evil. Ferdowsi's Shahnameh from the beginning to the end, especially in mythological and heroic periods, is the arena of conflict between the two armies: Ahura Mazda (symbol of good) and Iblis and Ahriman (symbol of evil) and human beings and the court, with the explanation that The negative personalities of Shahnameh are considered to be part of the army of the devil, the devil and the court, and the positive personalities are considered to be part of the corps of Ahura Mazda and the gods and men, which ultimately leads to the victory of the corps of good against the corps of evil. : 1385)

Therefore, the conclusion is that according to your Zoroastrianism, Ahuramazda is the creator of all goodness and is free from the creation of evil and evil and will never allow suffering and evil to reach the servants on his behalf. On the other hand, the "motivation" of the leader of the court and the forces of evil has no purpose other than to destroy the world and the creatures of Ormazd, and all his efforts are aimed at creating a good creation and, above all, man.

\section{Levi Strauss Thoughts}

\section{Here is a brief overview of Levi-Strauss's thinking:}

Structure: For Strauss, the structuralist view is "the search for the invariant element among superficial differences." (Strauss, 2006: 24) He considers the understanding of structure to depend on the understanding of momentum. As he puts it: "The concept of rotation lies at the heart of structural analysis. I even think that all the errors and abuses of the concept of structure are the result of not understanding that it is impossible to imagine structure apart from the idea of rotation. The structure cannot be reduced to one system. By system, I mean a group of elements and relationships that connect them to each other. To talk about the structure, it is necessary to have invariant relations between elements and relations between several sets; "In this way, one can move from one set to another by one rotation." (Ibid: 72). Wild Thought Before Levi-Strauss There were two different interpretations of the way primitive peoples thought, and in Strauss's term unwritten tribes: "The former considered primitive thought to be of lesser quality" (ibid .: 30), a prominent example of which is Bransilav. It is Malinowski. According to him, the minds of primitive people are "entirely determined by the basic necessities of life." (Same). This view is known as functionalism. 
The second style considers it fundamentally different than it considers the primitive thought to be. An example of this type of attitude is Levy Bruhl. He believes that the fundamental difference between primitive thought $[\ldots]$ and modern thought is that the former is entirely influenced by mystical and emotional representations "(ibid.); But from the point of view of Levi-Strauss, "there is no distinction between the way we think and those who are called primitive peoples" (ibid .: 67). There are two kinds of logic: one is primitive logic, which is based on obvious contradictions, perceptible attributes, concrete and objective things, for example, the difference between raw and cooked, wet and dry, man and woman, and the other is modern man, which depends on formal contradictions of completely abstract elements. + Andor is my logarithm. "(Leach, 1350: 135). In other words, "the primitive tribes discussed by LeviStrauss were as civilized as we are." "Rand, unless they use another system in marking." (Ibid: 139).

According to Levi-Strauss, "One of the fundamental differences between the way we think and the thinking of primitive peoples is the need for us to break things down into small pieces." (Strauss, 2006: 70): But in the basic idea of the goal "achieving a general knowledge of the world, in the shortest possible way. That is, in this type of thinking, if a person does not understand everything, he is not able to explain anything. (Ibid: 31 ).

Levi-Strauss has always emphasized that "the West has often, with its anthropological help, equated primitive societies with human childhood, and therefore condemned it for having more primitive and simpler ideas than the West." Primitive societies have myths, while the West has science and philosophy, and ...) »is not true. (Lecht, 1392: 125), therefore, "not only do human beings belong to a single humanity, but if we want to make a difference between ourselves, the presence of others is necessary." (Same). According to Hamid Enayat, the least virtue of such a theory is that it bases the claim of the inherent superiority of European nations over the socalled backward nations, which has been one of the main excuses of colonialism, both morally and It shakes science. "(Introduction by Levi Strauss, 1350: 7).

\section{Dual confrontations}

Now that we are familiar with primitive thought, it is better to recall that from Levi-Strauss's point of view, the function of this kind of thought is based on dual confrontations. According to Levi-Strauss, the structure of primitive thought is based on opposition. By learning the basic forms of language, our ancestors began to classify their world. "This classification is very rudimentary and has always been based on presence and absence: light / darkness, handmade / natural, up / down, covered / naked, sacred / unholy, and so on." (Bertens, 1391: 77).

In these contrasts, the first component is always preferred to the second. Of course, Leach protests Strauss' belief: "There is no doubt that the human brain wants to work with binary contrasts in all areas, but it can choose other methods in its work. . (Leach, 1350: 141).

\section{Nature and culture}

According to Levi-Strauss, among the dual confrontations, "the confrontation of what is manmade and what is natural (in simpler terms, the confrontation between culture and nature) is the most fundamental" (Bertens, 2012). : 78)

According to Strauss, "nature is those things in us that are the result of biological inheritance, but culture is the sum of things that come to us from the foreign tradition, that is, from education." (Charbonnie, 1372: 134). "From this point of view, culture and nature are against each other." (Ibid: 138). According to Freud, Strauss considers the unconscious nature to be dependent on nature and the conscious to be dependent on culture "(Leach: 178). According to him, the common features that are seen in different cultures "are not in the obvious realities of cultures but in their construction" (Ibid: 42). 
Levi-Strauss assumes that what distinguishes man from man, primitive man, is the difference between culture and nature "(Leach: 177). In his view, among the manifestations of culture (law, religion, art, cooking, tool making, etc.), it is language that has paved the way for the transition from nature to culture. "One of my goals has always been to prove that the difference between culture and nature is not instrumentalism, but speaking through words," he said. The great leap begins with the tongue. "(Charbonia, 1372: 136). Language in this sense means "any kind of language that can be imagined. Because the main feature of language is that it translatable; Otherwise it is not considered a language; "Because language is a device of signs that can be transformed into another device of signs according to a conversion process." (Same). For several reasons, "language is the highest cultural phenomenon [...]. "The most important reason is that language is the most complete of all the manifestations of culture that somehow form an apparatus." (Ibid: 137).

Of course, Levi Strauss says elsewhere that "art is the highest degree of conquest of nature by culture" (ibid .: 95); But this statement does not contradict what he said about language; Because he always considers art as a language. Therefore, in the transition from nature to culture, language precedes art.

\section{Hot and cold communities}

In Wild Thought, Levi-Strauss distinguishes between two types of society: hot and cold. In his view, the model of a warm society on which Western societies are built is comparable to thermodynamic machines (steam engines). They have the ability to do a lot of work; - It means creating order - but like steam engines, they also have a lot of waste and erosion; That is, the same disorder. And just like steam engines, they draw their power from the differences between their hot and cold components. Warm communities rely on internal differences to function. "Differences arise from social hierarchy." (Weisman, 1392: 90). "The emergence of this hierarchy is closely related to the invention of writing. Writing became a tool of power in the hands of one class to control other classes. "The first uses of writing were to devise rules and regulations, to contract, and to list property." (Ibid: 91). But the societies opposite them, the primitive societies, are considered cold because they have no writing. "Levi-Strauss sees these societies as wall clocks that work for a long time with the little force he has given them. The goal of these societies is to maintain their balance and minimize wear and tear "(Ibid: 94).

According to Levi-Strauss, time is linear in hot societies and cyclical in cold societies. In hot societies, "time is a dense sequence that every moment "It is rooted in the past and announces the future." (Ibid: 100); While cold (traditional) societies perceive the present at the same time as the past and at the same time parallel to it "(Ibid: 102). Of course, this does not mean that hot and cold societies are completely different from each other. As he himself says: "I have said and written many times and reminded that no society is absolutely hot or absolutely cold. "These are the theoretical concepts we need to formulate our hypotheses." (Strauss, 2006: 89).

\section{Confrontation in the story of Bahram Gore}

Bahram V (Bahram Gour) was the fifteenth emperor of Iran and Iran from the Sassanid dynasty, who ascended the throne in $421 \mathrm{AD}$ instead of his father and reigned until 438 AD. Uber was the religion of Mazdisna.

At the beginning, Lakhmian, who was handed over to the Sassanid puppet, was trained.

Goliath was the leader of the Jews and for this reason the Jews of Mars not only the Zoroastrian kingdom but also

The Jew is known as the king of history and legend.

In the confrontations that exist in this story, confrontations such as: hot and cold, ugly and beautiful, joy and sorrow 
Knowing that his kingdom was growing righteously reduced his joy and sorrow

(Shahnameh of Ferdowsi, Moscow Press, verse 110)

According to the king, the proud man tasted very hot and cold

(Ibid., Bit 684)

Good night and early in the morning come to the plain of Nakhjirgah (Ibid., Verse 952)

They all lit a fire in the desert, and the firewood burned (Haman, b. 956)

The air is straight, neither hot nor cold, green land and water azure (Ibid., B. 1101)

The game is not open to the world (Ibid., P. 1432)

Another confrontation can be planned between Iran and Iran and the confrontation between Iran, Turan, China, Rome and India.

Hemi Bajjkhadhzherzrmarzobum Basali Parishan Rud Bajorum (Ibid., P. 767)

So the consciousness came to leave Bhondobrom and go to China and Abad Boom (Ibid., B. 1420)

Confrontation in the characters of the story of Lenbek Abkash and Brahm Jahoud When Bahram Shah asks about these two characters, he hears such an answer.

Saqayast is this gentleman, a philanthropist and a good speaker (Ibid., P. 118)

Beik has been watering for half a day. Look at the other half of the guests. (Ibid., P. 119)

He does not want anything to be in the house today (Ibid., P. 120)

Brahm is irrelevant, where is the seven (ibid., P. 121)?

Derm Dardo Ganj and Dinar are also the same as Diba carpet or anything (Ibid., P. 121)

The Saqqa is needless in this need and poverty, and when Bahram Shah becomes the unknown guest of the Khan, the Khan expands and does not even hesitate to sell his Saqqa tools to provide the colorful Khan for his unknown guest. He shines and closes the door to Brahmi and gives him his cattle next to Esther. After the king returns, he calls both of them, and Velenbek loves him and rewards him. He gives and says that it is not punishable to spend a fortune on selfishness.

Another confrontation in this story is related to the religious confrontation that Bahram Gour, the representative of the Roman Zoroastrian religion, who considered himself the leader of the Christian world. Bahram in the first year of his reign entered the war with the Byzantine Empire, which had a religious background and began due to differences between Christians and Zoroastrians. The Armenian War was due to the pressure that Zoroastrians put on Armenian Christians and they were forced to emigrate. With Iran, first the Romans (Iranians) defeated the Iranians and then Bahram, with the help of Monzer, defeated the Romans and forced them to make peace.

He forced them to pay a ransom to Iran

Know that Alexander the Great came to Iran and destroyed this border of the web (Ibid., P. 118)

Vazan retreated to Caesarea, and the whole of Rome took up arms (ibid., B. 1426). 
Zoroastrianism and Abad Boom came to Iran (Ibid., B. 1427)

When Qaysar Sepah Kordolshkar Kashid Zachin Vakhtn Lashkar-e Amad Padid (Ibid., B. 1428)

I greet Zaqisar to the king, may this knowledge be eternal (Ibid., B. 1721)

If the greed of Zaqisar arises that your order is king in the world (Ibid., B. 1821)

The Chukhaqans of China heard these words and chose to fight against the army (Ibid., P. 11424).

In the Iranian judiciary, no one came to remember Zebraram (Ibid., B. 1425)

They went to the fire-worshipers with the veil (ibid., B. 1601).

Let's bring rice and zucchini to the wood and sugar (Ibid., P. 568)

\section{Result}

From what has been said in this research, it follows that the role of confrontation in Shahnameh is very prominent and many factors

It is one of the suckers of the heroes and the confrontation between the forces of good and evil and the basis of many stories of Shahnameh; and it has caused the demonic and Ahuraian forces to fight against each other. The character of heroes and heroines and the land can be seen in Shahnameh.

Such as: the contrast in the character of Rostam Vasfandiar;

Eating the tragedy of Esfandi's death Bahman was educated after Esfandiar's death and the destruction of the Zal family by Bahman

Esfandiar's son is all rooted in these confrontations, which is at its peak in Shahnameh and is an example for other epic works

According to Louis Estroe, the contrast we see in the Shahnameh contrasts with the fact that Strauss

He believes in double confrontation. In this confrontation, the first component is always superior to the second component. The confrontation in presence and absence, the confrontation between nature and culture, warm societies, etc ... It can be seen that each of them has its roots in wars and bitter and sweet events in Shahnameh.

PS

In general, opposition and contradiction means the accumulation of contradictions in one place, that is, if we consider the two meanings that are elusive and cannot be combined in a single place and time for a single direction. It is used to analyze myths, and the contrast in myths can be drawn along the opposite boundaries between death and life.

There is nature and culture, and raw materials and food. Understand and believe that these contradictions help explain the diversity of myths.

\section{References}

Teacher, Jaleh (1390). Language, culture and myth. Tehran: Moin.

Ibn Balkhi, (1385). Fars letter. Edited by Reynold Nicholson. Tehran: Myths. 
Ahmadi, Babak (1392). Text structure and interpretation. Centeral Tehran

Strauss, Levy (2006) Myth and Meaning. Interviews with Levi Strauss. Translated by Shahram Khosravi. Centeral Tehran.

Strauss, Levy (1386). Totemism. Translated by Massoud Rad, Tehran: Toos

Scholes, Robert (1383). An Introduction to Structuralism in Literature. Translated by Farzaneh Taheri. Tehran: Agah. Akbari Mafakher, Arash (1398). An Introduction to Iranian Demonology. Tehran: Trick.

Eliyadeh, Mircha (1393). Mythical Perspectives. Translated by Jalal Sattari. Tehran: Toos.

Oshidari, Jahangir (1389). Mazdisna Encyclopedia. Centeral Tehran.

Eagleton, Terry (2013). An Introduction to Literary Theory. Translated by Abbas Mokhber. Centeral Tehran.

Bastid, Rojeh (1391). Knowledge of mythology. Translated by Jalal Sattari. Tehran: Toos

Bertens, Hans (1391). Fundamentals of literary theory. Translated by Mohammad Reza Abolghasemi. Tehran: Fish.

Bresler, Charles (1393). An Introduction to Critical Theories and Methods. Translated by Mostafa Abedinifard. Edited by Hossein Payende. Tehran: Niloufar.

Balami, Muhammad ibn Jarir (1388). History of Bal'ami. Edited by Mohammad Taghi Bahar. By the efforts of Mohammad Parvingnabadi Tehran: Pilgrims

Bahar, Mohammad Taqi, editor (1387). History of Sistan. Tehran: Moin.

Bahar, Mohammad Taqi Corrector (unpublished). Complete histories and stories. Tehran: Eastern Stigma.

Bahar, Mehrdad (1389). Research in Iranian mythology. Tehran: Agah

Biruni, Abu Rihan (1389). Works of the rest. Translated by Akbar Dana Seresht. Tehran: Amir Kabir.

Payende, Hossein (1385). Criticism and Democracy. Tehran: Niloufar.

Tyson, Lice (1394). Theories of Contemporary Literary Criticism. Translated by Maziar Hassanzadeh - Fatemeh Hosseini. Edited by Hossein Payende. Tehran: Today's look.

Tafzali, Ahmad (1391). Wisdom menu. Thanks to Jaleh, the teacher. Tehran: Toos

Todorov, Tzutan (1392). Structural Poetry. Translated by Mohammad Nabavi. Tehran: Agah.

Jafari, Assadollah (1389). Ancient letter in the story plant. Tehran: Scientific and cultural

Dad, Sima (1387). Dictionary of Literary Terms. Tehran: Morvarid.

Dadgi, Farnbagh (1390). بندهش. Report by Mehrdad Bahar. Tehran: Toos.

Dostkhah, Jalil (1392). Avesta, the oldest Iranian songs and texts. ج جehran: Morvarid.

Dehbashi, Ali (1391). Nowruz. Collecting. Tehran: Thoughts

Safa, Zabihullah (1389). Epic in Iran. Tehran: Amir Kabir. 
Ferdowsi, Abolghasem (1392). Shah nameh. By the efforts of Saeed Hamidian. Volume One. Tehran: Qatre.

Fazlullah, Rashid al-Din (1392). Comprehensive histories. Edited by Mohammad Roshan. 1 . Tehran: Written Heritage Research Center.

Color, Jonathan (1390). Literary theory. Translated by Hussein Shaykh al-Islami, Tehran: Ofogh.

Christian Sen, Arthur Emmanuel (1393). Examples of the first man and the first prince in the legendary history of Iran. Translated by Jaleh Amoozgar and Ahmad Tafazli. Tehran: Cheshmeh.

Yahaqi, Mohammad (1369). Culture of myths and fictional allusions in Persian literature. Tehran: Soroush

Amoozgar, Jaleh, (2001), The Duality of the Good and the Bad and the False Brotherhood of the Good in the Valley of Zoroastrian Ethics, Fourth Edition, Myth Publishing, Tehran.

2005), _-), Mythical History of Iran, Samat, Tehran.

Teacher, Jaleh; Tafzali, Ahmad, (1375), The Story of Zoroastrian Life, Third Edition, Cheshmeh Publishing, Tehran.

Wiseman, Boris and Judy Goz (2013). Levi Strauss. New translation by Hamidian, Saeed, (1992), Introduction to Ferdowsi Thought and Art, Tehran Center Publishing.

- Tehran: Kazazi Campus, Mir Jalaluddin, (2000), Bastan Letter, First Edition, Samat Publishing, Tehran.

Ferdowsi, Abolghasem (1392). Shah nameh. By the efforts of Saeed Hamidian. Volume 7. Tehran: Drop. 